\title{
APPLICATION OF SEQUENTIAL TREND ANALYSIS FOR DISCHARGE CHARACTERISATION OF VIPAVA KARSTIC SPRINGS, SLOVENIA
}

\author{
UPORABA SEKVENČNE ANALIZE TRENDOV ZA UGOTAVLJANJE \\ ZNAČILNOSTI ODTOKA KRAŠKIH IZVIROV VIPAVE, \\ SLOVENIJA
}

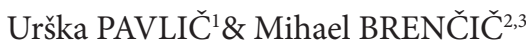

\begin{abstract}
UDC 556.36:551.435.8(497.47)

Urška Pavlič \& Mihael Brenčič: Application of sequential trend analysis for discharge characterisation of Vipava karstic springs, Slovenia
\end{abstract}

The discharge of Vipava springs and precipitation data of their recharge area have been statistically analyzed and presented in this paper to provide some additional insight into the hydrological regime of the aquifer. Monotone and sequential trends have been evaluated and interpreted based on a 45-year data measurement period between 1960 and 2004. The springs have a typical karstic regime with short-term periods of high discharge and long-term periods of mean and low discharge values. The ratio of low, mean and high discharges is about 1:10:100. The majority of the springs' groundwater comes from precipitation in the recharge area. Supplementation of two different statistical analyses for sequential trend detection was applied to annual decile discharge values (1960-2004) due to the subjectivity of results interpretation. The first method involved the use of rescaled adjusted partial sums (RAPS) and the second non-parametric sequential Mann-Kendall trend detection. The purpose of the investigation was to determine if and to what extent the length and trend line direction of sub-periods differ between different annual decile values of Vipava springs and to what extent decile values are related to annual precipitation. Sequential trend analysis confirmed similarity in hydrological conditions between some neighbouring discharge decile values but not in others. This analysis also showed that the length of sub-periods and their linear trend direction differed with respect to low, mean and high annual decile discharge values. Keywords: Vipava karst spring, monotone trend, rescaled adjusted partial sums, non-parametric sequential Mann-Kendall test, decile comparison.

\author{
Izvleček UDK 556.36:551.435.8(497.47) \\ Urška Pavlič \& Mihael Brenčič: Uporaba sekvenčne analize \\ trendov za ugotavljanje značilnosti odtoka kraških izvirov \\ Vipave, Slovenija
}

Prispevek podaja način statističnih obdelav pretokov izvirov Vipave $\mathrm{z}$ namenom vpogleda $\mathrm{v}$ značilnosti odtoka na območju kraško razpoklinskih vodonosnikov. Statistične analize temeljijo na izračunu sekvenčnih trendov letnih decilnih vrednosti 45 letnega niza hidroloških opazovanj med leti 1960 in 2004. Za izvire Vipave so značilna krajša trajanja visokih in daljša obdobja srednjih in nizkih voda. Razmerje med nizkimi, srednjimi in visokimi pretoki znaša približno 1:10:100. Večina vode proti izvirom odteka iz neposrednega padavinskega prispevnega zaledja izvirov. Da bi zmanjšali napako zaradi subjektivnosti rezultatov, je bil izračun sekvenčnih trendov izveden komplementarno po dveh različnih metodah in sicer po metodi umerjenih delnih vsot (RAPS) in $\mathrm{z}$ neparametrično analizo sekvenčnih trendov po metodi Mann Kendall. Z metodama smo določili pod-obdobja znotraj posameznih časovnih vrst, nato pa smo na podlagi rezultatov ugotavljali podobnosti med posameznimi časovnimi vrstami, ki so jih predstavljale letne decilne vrednosti pretokov izvirov Vipave. Analize sekvenčnih trendov so potrdile podobnosti med nekaterimi decilnimi vrednostmi, saj so bile dolžine in smeri trendov pod-obdobij podobni med nizkimi, srednjimi in visokimi decilnimi vrednostmi pretokov.

Ključne besede: kraški izviri Vipave, sekvenčni trendi, umerjene delne vsote, neparametrični sekvenčni Mann Kendall test, primerjava decilov.

\footnotetext{
${ }^{1}$ Slovenian Environmental Agency, Vojkova 1b, Ljubljana, Slovenia, e-mail: ursa.pavlic@gov.si

${ }^{2}$ Department of Geology, Faculty of Natural Sciences and Engineering, University of Ljubljana, Aškerčeva ulica 12, Ljubljana,

Slovenia, e-mail: mihael.brencic@ntf.uni-lj.si

${ }^{3}$ Department of Hydrogeology, Geological Survey of Slovenia, Dimičeva ulica 14, Ljubljana, Slovenia

Received/Prejeto: 3.7.2010
} 


\section{INTRODUCTION}

The analysis of input and output functions and their time series can help to determine and characterize the nature of hydrodynamic processes in karstic hydrological systems (Mangin 1994). Detailed statistical analyses of various hydrological and meteorological time series data can provide valuable information about a karstic aquifer, its parameters and hydrological regime. There are many approaches to hydrological time series in karst hydrology, with trend analyses - most frequently monotone trends (Helsel \& Hirsch 1991; Hipel \& McLeod 1994; Yue et al. 2002; Ulaga 2002; Önöz \& Bayazit 2003; Cheng \& Chunyuan 2004) and sequential and shift trend approaches (Sneyers 1990; Tonkaz et al. 2007; Bonacci 2007; Bonacci \& Andrič 2008). Sequential trend analysis had been used to detect trends not detectable with monotone trend analysis. They were intended to evaluate man - induced changes, such they are industrial and agricultural processes followed by significant population growth and in- fluences of water management (Moraes et al. 1998), to estimate climate changes (Gerstengarbe \& Werner 1999; Hamed 2008) or simply to detect trends, data shifts, data clustering, irregular fluctuations and periodicities. Time series analyses very often represent starting point for further investigation (Garbrecht \& Fernandez 1994; Bonacci 2007).

In this paper, monotone and sequential trend tests were performed on annual discharges of the Vipava springs system. The main purpose of the investigation was the characterisation of Vipava karstic aquifer with comparison between low, medium and high hydrological condition and the detection of possible subperiods of trends or periodicities within long term discharge time series of Vipava springs, which will represent valuable information in understanding groundwater reserves and quantitative status of Vipava aquifer representing important water resource.

\section{GENERAL SETTING}

The Vipava springs system is located in the western foothills of the Nanos massive, which spreads from the flysch margin of the Vipava valley. Seven permanent springs are to be found within a radius of about 300 metres from Vipava town (Fig. 1) with average discharge of $6.71 \mathrm{~m}^{3} / \mathrm{s}$. Vipava springs react simultaneously to precipitation in the recharge area. Lowest discharges are typical for summer months with minimum in July and highest discharges are typical for April and November. Average water temperature is $9.5^{\circ} \mathrm{C}$ and oscillates between $8.5^{\circ} \mathrm{C}$ and $10^{\circ} \mathrm{C}$ (Janež et al. 1997).

The springs are located in a region where the deepest erosion of low permeable flysch beds is present (Janež et al. 1997). Quaternary deposits have partly filled the valley, resulting in the delta-like appearance of the springs. The lateral boundaries of the aquifer are represented by the flysch beds of the Bela stream valley, Vipava valley and Pivka basin, although some waters from the flysch also drain towards Vipava springs. The central part of Vipava springs' recharge area is composed of highly-permeable Nanos and Hrušica karstic massifs,

Fig. 1: Seven permanent Vipava springs: 1: Pri kapelici; 2: Pod lipco; 3: Za Perkavcovim mlinom; 4: Izvir iz Vipavske jame; 5: Za gradom; 6 \&7: Pod farovžem (modified after Janež et al. 1997).

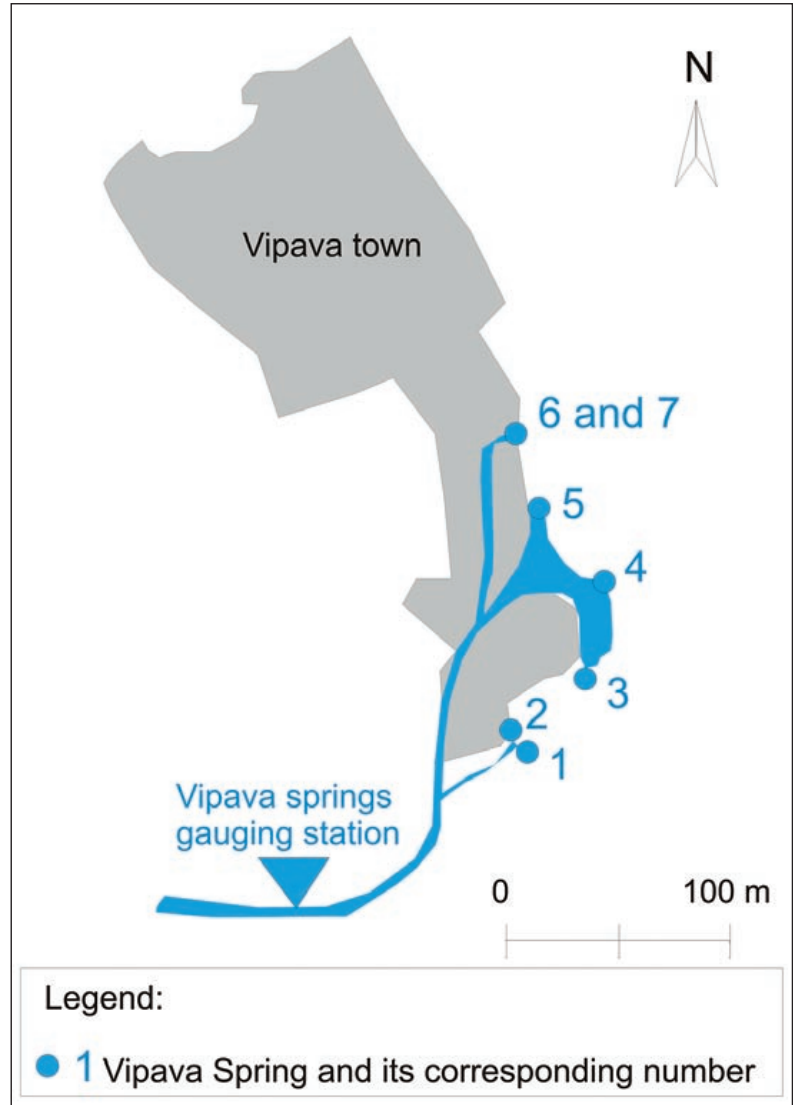




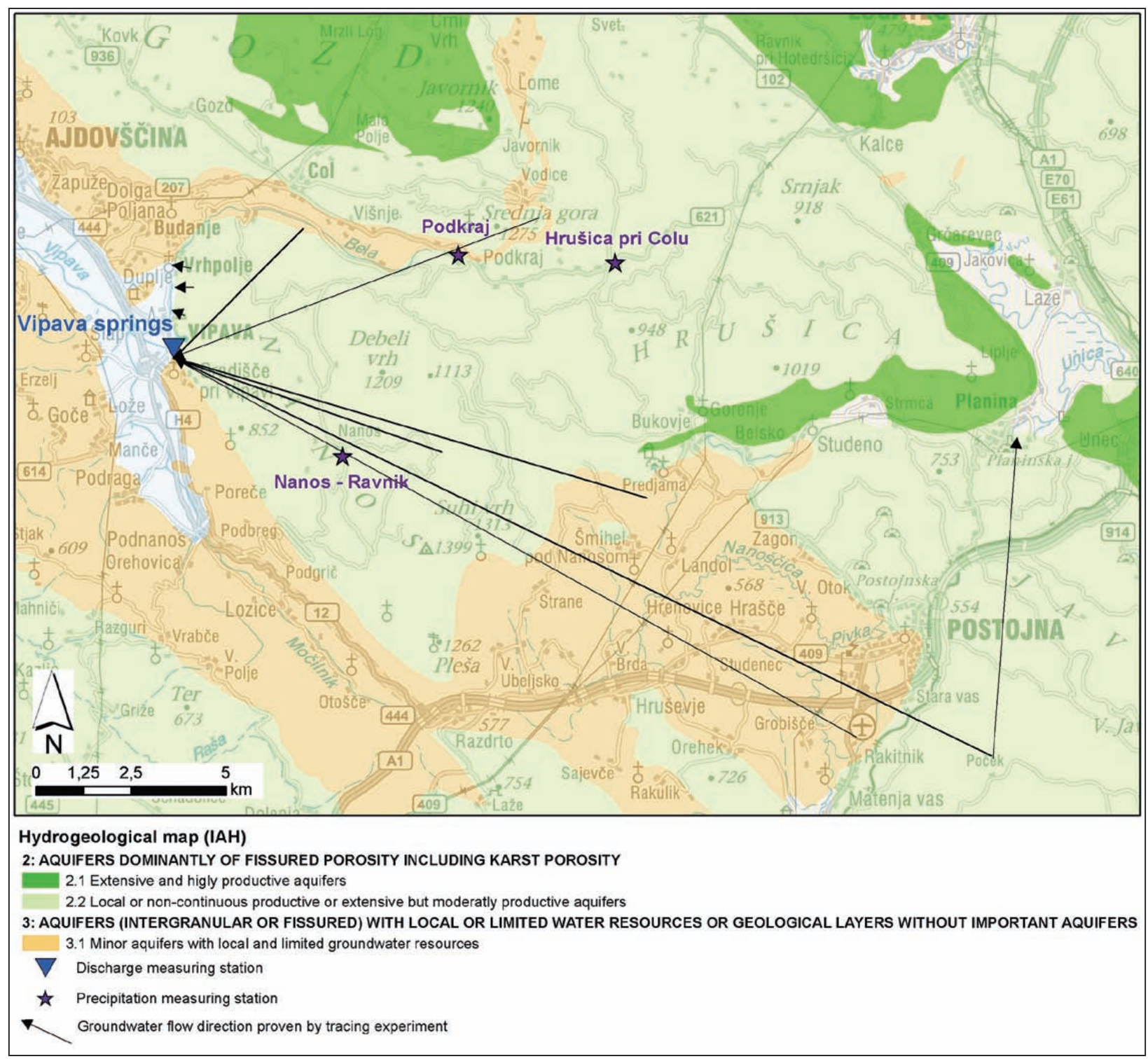

Fig. 2: Hydrogeological map of the Vipava springs recharge area with directions of proven groundwater connection (modified after Petrič 2002).

consisting of Cretaceous and Jurassic limestone (Fig. 2). The exact depth of flysch below the carbonate aquifer is not known. Geological analysis suggests that the flysch layer in the Nanos massif area is deeper than that of the Hrušica massif. The belt of Jurassic and upper Triassic dolomites on the fringe of the Hrušica massif has a lower permeability than the Cretaceous limestones of the Nanos massif (Petrič 2002).

The main recharge area of Vipava springs is within the Nanos and Hrušica regions, with a total recharge area of $149 \mathrm{~km}^{2}$ estimated by water balance calculations (Petrič 2000). The connection of Vipava springs with the Pivka basin and the western part of the Javorniki massif has been proven by tracing experiments (Kogovšek et al.
1999). Just as flow direction is related to hydrological conditions (Habe 1970; Habič 1989; Behrens et al. 1997), different groundwater flow directions also exist in the wider Bela valley area (Fig. 2). During low water conditions, the Bela stream partly sinks into the Nanos massif and acts as a supply for Vipava springs. At higher water stages, intermittent springs appear at the western margin of the Nanos massif and water flows into the Bela stream (Baker et al. 2001; Petrič 2000).

The climate of the Vipava valley is influenced by both mild coastal temperatures and the harsh alpine conditions of the high Nanos plateau above; consequently weather conditions are a mixture of Mediterranean and Alpine regimes. In the latter, abundant precipitation, 
frequent snow and low air temperatures are present. The highest amount of precipitation occurs in November, while snow cover on Nanos can last from November until May. The lowest levels of precipitation can be expected in summer, with a minimum in July. The Vipava
River has a Dinaric pluvio-nival regime in which spring and autumn peaks are fairly similar, while differences between winter highs and summer lows are pronounced (Bat et al. 2008).

\section{METHODS}

\section{DISCHARGE AND PRECIPITATION DATA}

All data, used in this paper was gathered in accordance of national monitoring programs in the Environment Agency of the Republic of Slovenia. Discharge and precipitation time series for period between years 1960 and 2004 were used.

Characteristic values of annual discharges of Vipava springs were defined based on daily discharge values. The gauging station for the Vipava springs system is located in Vipava borough. At the station, the discharge of all seven springs is measured commonly (Fig. 1).

In the recharge area of Vipava springs there are three precipitation stations; Podkraj, Hrušica pri Colu and Nanos - Ravnik with longer time series of daily precipitation amount. For the purpose of the analyses presented in the paper, data from Podkraj precipitation station were used. It is positioned on the fringe of the Nanos massif at an altitude of $799 \mathrm{~m}$ above sea level (Fig. 2 ) and it is a station with longest continuous record between 1960 and 2004.

\section{STATISTICAL METHODS}

The statistical methods implemented in this study include order statistics, monotone trend analyses, Spearman's rank correlation test, Rescaled Adjusted Partial Sums - RAPS and the Mann-Kendall test.

Decile value is defined as one of the values of the variable that divide the increasingly ordered distribution of the variable into ten groups having equal frequencies. For example, the ninth decile is the value below which lie $90 \%$ of the population.

$\mathrm{Di}=\mathrm{X}_{(\mathrm{n}+1) *} \times \mathrm{i}$

where $\mathrm{n}$ is the sample size of $\mathrm{Xi}$ and $\mathrm{i}$ is the fraction of data less than or equal to the decile value (e.g. for the $1^{\text {st }}, 2^{\text {nd }}$ and $3^{\text {rd }}$ deciles, $i=0.1,0.2$ and 0.3 respectively). For each decile value in this paper, a time series of 45 observations was defined.

Decile time series were tested for monotone trends using a fit of linear regression; the dependent variable was represented by annual decile discharges and the independent variable as time in years (Hipel \& McLeod 1994). The relationship between annual values of discharge and precipitation was tested using the same method, with the test implemented via use of the non-parametric Spearman's rank correlation coefficient $\rho$, with a $95 \%$ confidence limit. The Spearman's rank correlation coefficient is defined as the sum of the differences between dependent $\mathrm{y}$ and independent $\mathrm{x}$ data and is expressed as (Yue et al. 2002):

$\tilde{\mathrm{n}}=\frac{6 \sum_{i=1}^{n}\left(R\left(x_{i}\right)-R\left(y_{i}\right)^{2}\right.}{n\left(n^{2}-1\right)}$

The Rescaled Adjusted Partial Sums (RAPS) method (Garbrecht \& Fernandez 1994) is calculated as:

RAPS $_{k}=\sum_{n=1}^{k} \frac{Y_{t}-\bar{Y}}{S_{Y}}$

where $Y_{t}$ is the particular value at time $t ; \bar{Y}$ is sample mean; $S_{Y}$ is sample standard deviation; $\mathrm{n}$ is the number of values in the time series $(n=1,2 \ldots, \mathrm{k})$ and $\mathrm{k}$ is the counter limit of the current summation. A visualisation approach based on RAPS overcomes both small systematic changes in records and variability of data. RAPS visualisation highlights trends, shifts, data clustering, irregular fluctuations and periodicities in the record.

The sequential Mann-Kendall test is computed using ranked values, $\mathrm{y}_{\mathrm{i}}$, of the original analyzed values, $\mathrm{x}_{\mathrm{i}}$. The magnitudes of $y_{i},(i=1, \ldots, N)$ are compared with $y_{j}$, $(j=1, \ldots, i-1)$. For each comparison, the cases where $y_{i}>y_{j}$ are counted and denoted by $n_{i}$. A statistic $t_{i}$ can therefore be defined as: $t_{i}=\Sigma n_{i}$ (Mohsin \& Gough 2009). For a large $N, t_{i}$ is normally distributed with mean $E\left(t_{i}\right)$ and variance $\operatorname{Var}\left(\mathrm{t}_{\mathrm{i}}\right)$ given by:

$$
\begin{aligned}
& E\left(t_{i}\right)=\frac{N(N-1)}{4} \\
& \operatorname{Var}\left(t_{i}\right)=\frac{N(N-1)(2 N+5)}{72}
\end{aligned}
$$


The sequential values of the statistic $\mathrm{U}\left(\mathrm{t}_{\mathrm{i}}\right)$ can then be computed as (Sneyers 1990):

$U\left(t_{i}\right)=\frac{\left[t_{i}-E\left(t_{i}\right)\right]}{\sqrt{\operatorname{Var}\left(t_{i}\right)}}$

\section{RESULTS AND DISCUSSION}

Vipava springs have a typical karstic hydrological regime, reflected by short high-discharge episodes and longer periods of average and low discharge (Petrič 2000). In the 45-year period between 1960 and 2004, minimum discharge was $0.73 \mathrm{~m}^{3} / \mathrm{s}$, average discharge was $6.71 \mathrm{~m}^{3} / \mathrm{s}$ and maximum discharge $69.81 \mathrm{~m}^{3} / \mathrm{s}$. The ratio between low, average and high discharges was therefore approximately 1:10:100.

During 1960-2004, maximum discharges were mostly detected in November and minimum discharges were typical for summer months. At Podkraj precipitation station, an annual minimum of $1662 \mathrm{~mm}$ and an annual maximum of $3242 \mathrm{~mm}$ were recorded in 2003 and 1965 , respectively.

Comparison of discharge and precipitation data shows that for all decile classes, Spearman's rank correlation is statistically significant at the $95 \%$ confidence limit. It was determined that in general, low discharge deciles show a lower association with precipitation than high discharge decile values (Fig. 3). This association is highest at the $8^{\text {th }}$ decile time sequence $(\rho=0.80)$, declining to $\rho=0.73$ in the $9^{\text {th }}$ decile, which at the same time represents a median value of Spearman correlation coefficients. This indicates that very high water stages of Vipava springs' hydrological regime differ from other high decile oscillations.

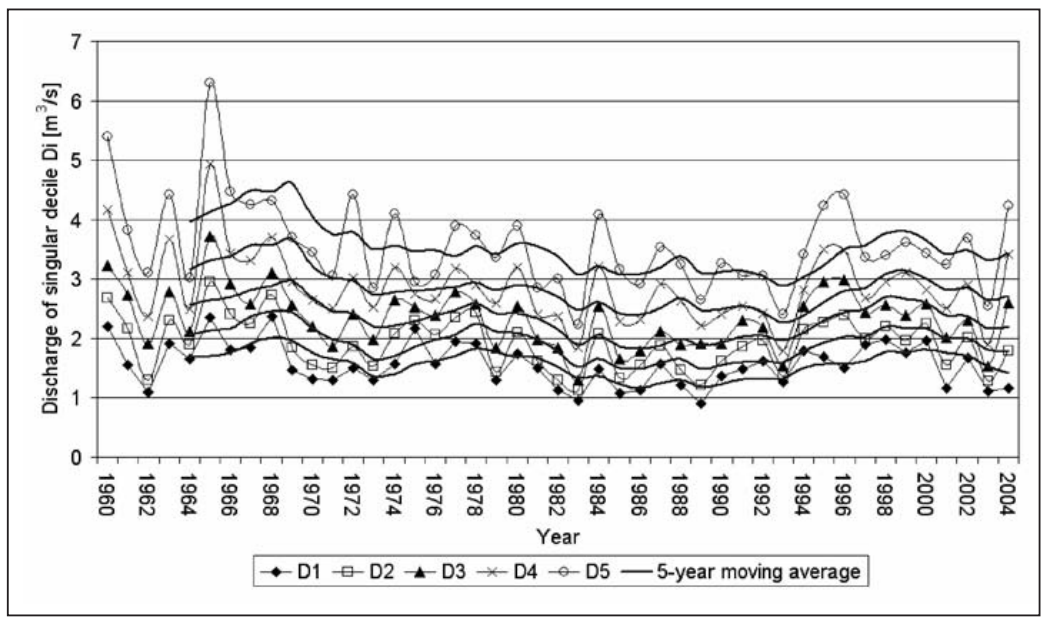

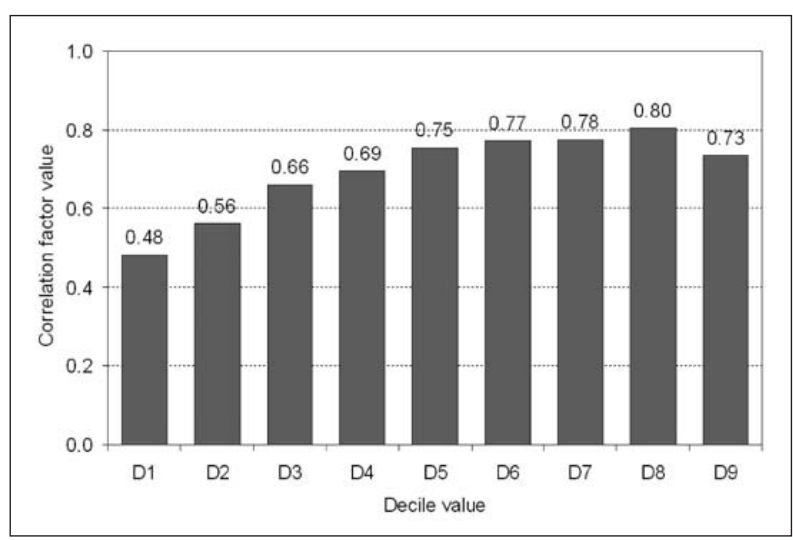

Fig. 3: Spearman's rank correlation coefficient between total annual precipitation and discharge decile values.

A 5-year moving average was used on all decile time series data to smooth out short-term fluctuations and emphasise long-term trends or cycles (grey curves in Figs. 4 \& 5). A decline over time of the filtered decile time series is not as evident as is the case for the non-filtered series. For decile discharge values equal to or lower than 3, six major shifts can be detected from the trend curve, beginning with increasing values from 1960 until 1969 and ending with decreasing time sequence values from 1998 until the end of the data collection period. Other shifts in the moving average trend lines were also detected in the years 1973, 1978, and 1986 (Fig. 4). For $4^{\text {th }}$ and $5^{\text {th }}$ decile values, only five major shifts in the moving average trend can be observed, as the shift occurring in 1978 is not as evident

Fig. 4: 5-year moving average for discharge decile values lower or equal to median. 


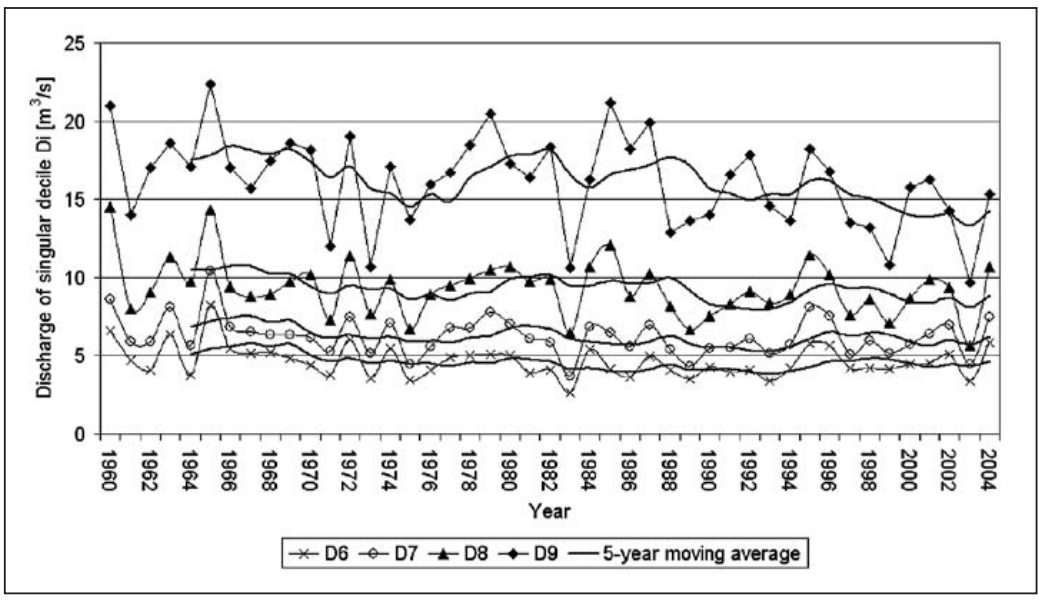

Fig. 5: 5-year moving average for discharge decile values higher than median.

Moving average trend evaluations were followed by two sequential trend tests based on RAPS and Mann-Kendall methods. RAPS and Mann-Kendall values were calculated to detect shifts in singular time series' trends (Figs. 6, 7, $8 \& 9$ ). The results of both methods are obtained subjectively from oscillations of new calculated values and therefore

here as it is for lower deciles (Fig. 4). Trend curves of $6^{\text {th }}$, $7^{\text {th }}$ and $8^{\text {th }}$ deciles do not show any trend shifts, although a gradual decrease in values over time is evident (Fig. 5 ). The $9^{\text {th }}$ decile curve shows a quite chaotic shape (Fig. 5), with oscillations showing rapid movements during the time sequence. However, although moving average trends can provide a general insight into the similarities and dissimilarities of trends between various sub-period time series, they cannot reveal the exact moment of trend shift occurrence.

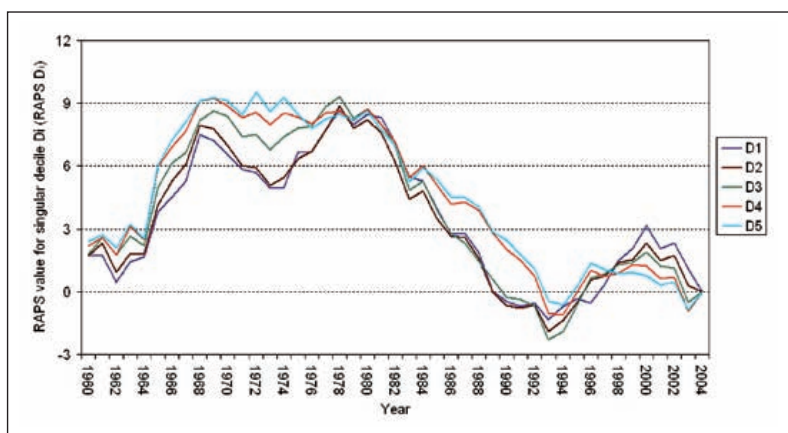

Fig. 6: RAPS values in time calculated for discharge decile values.

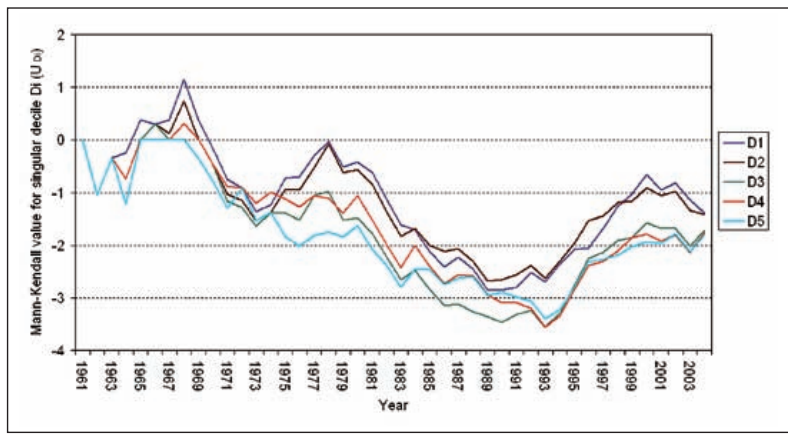

Fig. 8: Mann-Kendall values in time calculated for discharge decile values. their accuracy may be reduced. To avoid uncertainty, only those results determined by both RAPS and MannKendall methods were evaluated in the interpretation. Shifts in trends detected by only one of the methods used were therefore disqualified from further analysis.

Results revealed that for some time series analyzed, equal or similar sub-periods were determined, while for others, sub-periods differed (Figs. 10, 11 \& 12). By combining both methods of sequential trend analysis, three major groups of analyzed time series were distinguished.

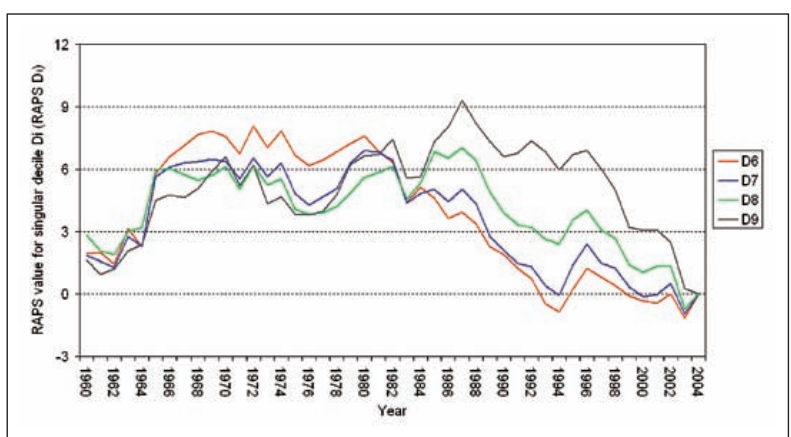

Fig. 7: RAPS values in time calculated for discharge decile values.

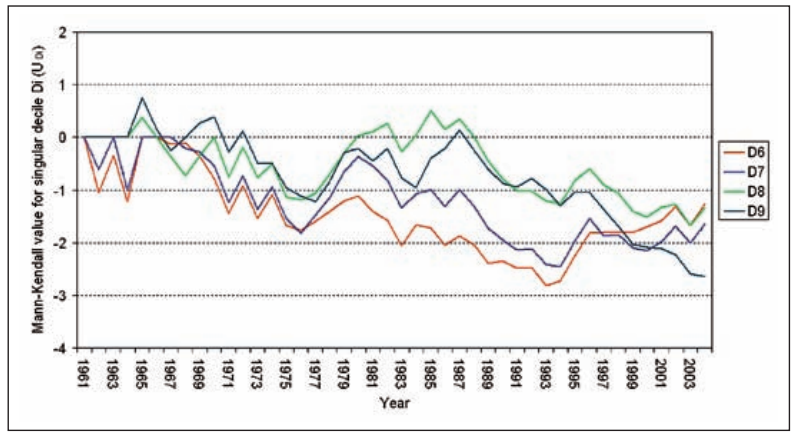

Fig. 9: Mann-Kendall values in time calculated for discharge decile values. 


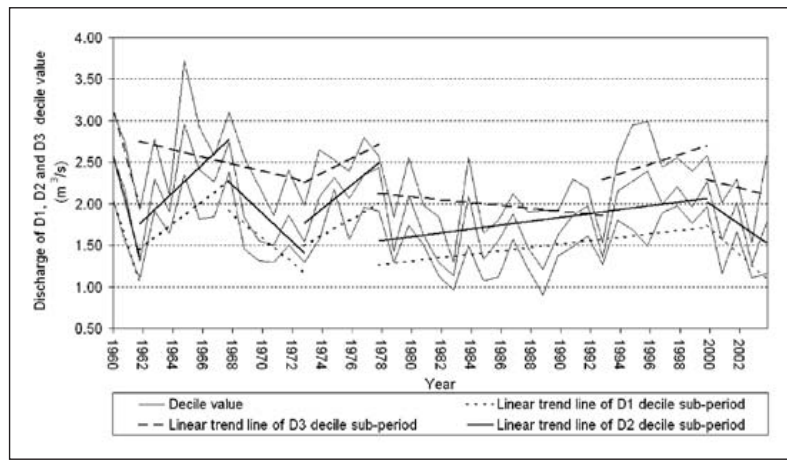

Fig. 10: $1^{\text {st }}, 2^{\text {nd }}$ and $3^{\text {rd }}$ discharge decile values with linear trend lines of sub-periods detected by sequential methods.

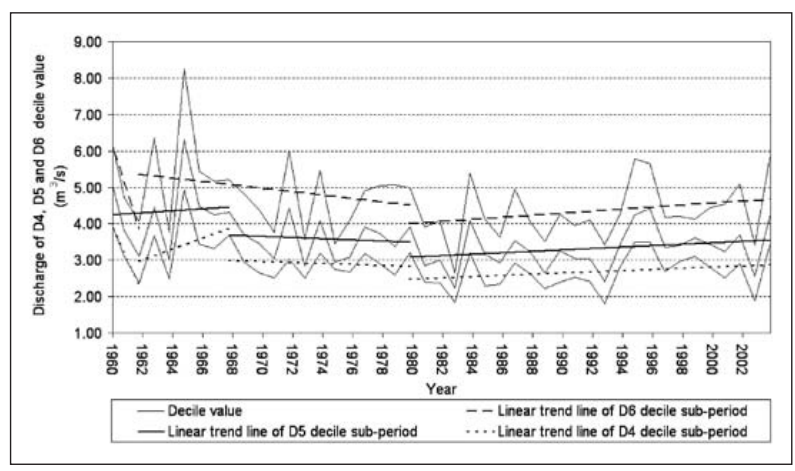

Fig. 11: $4^{\text {th }}, 5^{\text {th }}$ and $6^{\text {th }}$ discharge decile values with linear trend lines of sub-periods detected by sequential methods.

The first group includes the time series of $1^{\text {st }}$ and $2^{\text {nd }}$ decile values, where five shifts in trend were evident (Tab. 1). The second group refers to $4^{\text {th }}, 5^{\text {th }}$ and $6^{\text {th }}$ decile value time series, where three shifts in trend were detected, while the final group consists of $7^{\text {th }}$ and $8^{\text {th }}$ decile value data, for which four shifts in trend were elucidated

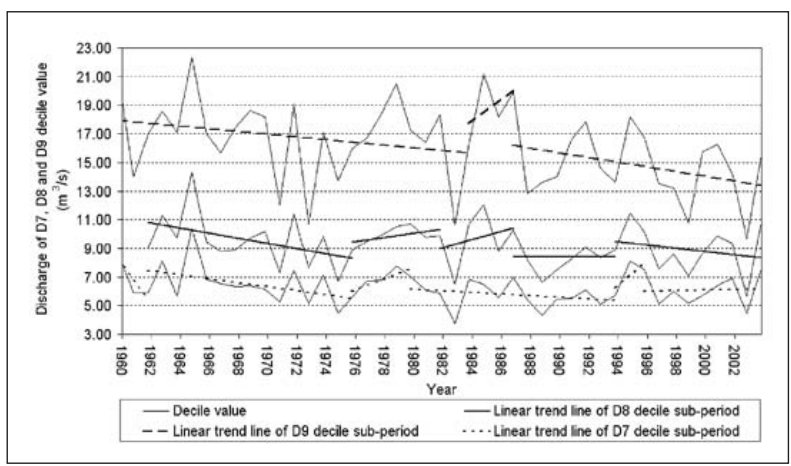

Fig. 12: $7^{\text {th }}, 8^{\text {th }}$ and $9^{\text {th }}$ discharge decile values with linear trend lines of sub-periods detected by sequential methods.

(Tab. 1). Similarities are most evident between the first and second groups of decile values.

Based on the results of sequential trend analyses, it can be seen that some annual decile time series oscillate in a similar fashion, but others differ. This affinity is more evident when comparing low and mean water levels, while high and very high annual water periods are less similar (Figs. 10, $11 \& 12$ ).

Tab. 1: Major groups of discharge decile values, determined from RAPS and Mann-Kendall value oscillations.

\begin{tabular}{|c|c|c|c|c|c|}
\hline \multicolumn{2}{|c|}{ 1 and 2} & \multicolumn{2}{c|}{ from 4 to 6 } & \multicolumn{2}{c|}{8 and 9 } \\
\hline start & end & start & end & start & end \\
\hline 1960 & 1962 & 1960 & 1962 & 1960 & 1962 \\
\hline 1962 & 1968 & 1962 & 1968 & 1962 & 1976 \\
\hline 1968 & 1973 & 1968 & 1980 & 1976 & 1982 \\
\hline 1973 & 1978 & 1980 & 2004 & 1982 & 1994 \\
\hline 1978 & 2000 & & & 1994 & 2004 \\
\hline 2000 & 2004 & & & & \\
\hline
\end{tabular}

\section{CONCLUSIONS}

This paper has presented results from the comparison of the annual discharges and precipitation in the recharge area of the Vipava karstic springs system. Moving average trends were calculated to detect the general characteristics of associations between precipitation and discharge during the years 1960-2004. Sequential trend analyses were subsequently performed to identify different groups of discharge decile values with respect to duration of subperiod and direction of sub-trends.

Moving average analysis has proven to be an effective tool for gaining general insight into the shifts of trends in time series, but cannot reveal the exact time of shift occurrence. Two methods of sequential trend analysis were thus used to avoid subjectivity of results. The combination of Mann-Kendall and RAPS sequential trend tests has been shown to be a suitable way of distinguishing the different characteristics of spring discharges.

Sequence trend analysis, performed on annual decile discharge values, revealed changes in hydrological regime between low, mean and high water stages.

The association between precipitation in the recharge area and discharge decile values of the springs is high, which indicates that the greatest amount of spring water is recharged from the Nanos plateau. The magnitude of the correlation factor suggests that the connec- 
tion between precipitation and high discharge periods is greater than that between precipitation and low discharge.

In the case of Vipava springs, at low-water hydrological stages when annual decile values are equal to or lower than $2^{\text {nd }}$ decile discharge, shifts in the trends of detected sub-periods coincide with one another. Another two groups of similar time series data have been identified, between $4^{\text {th }}$ and $6^{\text {th }}$ and between $7^{\text {th }}$ and $8^{\text {th }}$ annual decile values. Similarities between time series are greater for low annual decile values than for high water stages. It can be concluded, therefore, that periods of low water levels on an annual scale represent a more predictable and stable hydrological situation than high water stages. In a high water situation, Vipava springs shows a specific and unpredictable hydrological regime, with sub-periods of the $9^{\text {th }}$ decile discharge time series differing greatly from all other analyzed time series data oscillations.

The method described in the paper is example of detailed trend analysis of long-term discharge data time series of big karstic spring. The method applied can be used as a starting point in the study of climate influences on water cycle of particular karstic spring, and it can predict trends in groundwater abstraction or other anthropogenic influences on discharge. With the method applied one can get insight in low level groundwater behaviour, which can help in understanding the prolongation of groundwater reserves at low-water conditions. In future Vipava should be compared with other karstic groundwater outflows in Dinaric karst of Slovenia.

\section{REFERENCES}

Baker, G., Petrič, M., Parkin, G. \& Kogovšek J., 2001: Medsebojni vpliv površinske in podzemne vode potoka Bele in izvirov Vipave v jugozahodni Sloveniji.- Acta carsologica, 30,2, 217-238.

Bat, M., Dolinar, M., Frantar, P., Hrvatin, M., Kobold, M., Kurnik, B., Nadbah, M., Ožura, V., Uhan, J. \& F Ulaga, 2008: Vodna bilanca Slovenije 1971-2000.Ministrstvo za okolje in prostor, Agencija Republike Slovenije za okolje, pp. 119, Ljubljana.

Behrens, H., Benischke, R., Kass, W. \& M. Zupan, 1997: Results of the Vipava Area - The Second Tracing Experiment in Spring 1994.- Acta carsologica, Karst Hydrogeological Investigations in South - Western Slovenia, 26, 295-301.

Bonacci, O. \& I. Andrić, 2008: Hidrologija ponornih rek Like in Gacke (Hrvaška).- Acta carsologica, 37,2-3, 185-196.

Bonacci, O., 2007: Analysis of long-term (1878-2004) mean annual discharges of the karst spring Fontaine de Vaucluse (France).- Acta carsologica, 36,1, 151-156.

Garbrecht, J. \& G.P. Fernandez, 1994: Visualization of Trends and Fluctuations in Climatic Records.- Water Resources Bulletin, 30,2, 297-306.

Gerstengarbe, F.W. \& P.C. Werner, 1999: Estimation of the Beginning and End of Recurrent Events Within a Climate Regime.- Climate Research, 11, 97-107.

Habe, F., 1970: Predjamski podzemeljski svet.- Acta carsologica, 5, 5-94.
Habič, P., 1989: Kraška bifurkacija Pivke na jadransko črnomorskem razvodju. Acta carsologica, 18, 233 264.

Hamed, K.H., 2008: Trend Detection in Hydrologic Data: The Mann-Kendall Trend Test Under the Scaling Hypothesis.- Journal of Hydrology, 349, 350-363.

Helsel, D.R. \& R.M. Hirsch, 1991: Statistical Methods in Water Resources.- Chapter A3, Book 4, Hydrologic Analysis and Interpretation, Techniques of WaterResources Investigations of the United States Geological Survey, Elsevier, pp. 522, Amsterdam.

Hipel, K.W. \& A.I. McLeod, 1994: Time Series Modelling of Water Resources and Environmental Systems,Developments in Water Science, Elsevier, pp. 1013, Amsterdam.

Janež, J., Čar, J., Habič, P. \& R. Podobnik, 1997: Vodno bogastvo Visokega krasa: ranljivost kraške podzemne vode Banjšic, Trnovskega gozda, Nanosa in Hrušice.Geologija, pp. 167, Idrija.

Kogovšek, J., Knez, M., Mihevc, A., Petrič, M., Slabe, T.\& S. Šebela, 1999: Military Training Reserve in Kras (Western Slovenia).- Environmental Geology, 38, 1, 69-76.

Mangin, A., 1994: Karst Hydrogeology.- In: Gilbert, J. et al. (eds.) Groundwater Ecology, Academic Press, pp. 43-67, San Diego.

Mohsin, T. \& W.A. Gough, 2009: Trend Analysis of Long-term Temperature Time Series in the Greater Toronto Area (GTA).- Theoretical and Applied Climatology, 98, 3-4. 
Moraes, J.M., Pellegrino, G.Q., Ballester, M.V., Martinelli, L.A., Victoria, R.L. \& A.V. Krusche, 1998: Trends in Hydrological Parameters of a Southern Brazilian Watershed and its Relation to Human Induced Changes.- Water Resources Management, 12, 295, 43-67, 311.

Önöz, B. \& M. Bayazit, 2003: The Power of Statistical Tests for Trend Detection.- Turkish Journal of Engeneering \& Environmental Sciences, 27, 247-251.

Petrič, M., 2000: Značilnosti napajanja in praznjenja kraškega vodonosnika $v$ zaledju Vipave.- $\mathrm{PhD}$ thesis. Naravoslovnotehniška fakulteta v Ljubljani, pp. 151.

Petrič, M., 2002: Characteristics of recharge-discharge relations in karst aquifer.- Založba ZRC, pp. 154, Postojna-Ljubljana.
Sheng, Y. \& W. Chunyuan, 2004: The Mann Kendall Test Modified by Effective Sample Size to Detect Trend in Serially Correlated Hydrological Series.- Water Resources Management, 18, 201-218.

Sneyers, A., 1990: On Statistical Analysis of Series of Observations.- World Meteorological Organization, pp. 192, Geneva.

Tonkaz, Z., Cetin, M. \& K. Tulucu, 2007: The Impact of Water Resources Development Projects on Water Vapour Pressure Trends in a Semi-arid Region, Turkey.- Climatic Change, 82, 195-209.

Ulaga, F., 2002: Trendi spremljanja pretokov slovenskih rek.- Dela, 18, 93-114.

Yue, S., Pilon, P. \& G. Cavadias, 2002: Power of the Mann Kendall and Spearman's Rho Tests for Detecting Monotonic Trends in Hydrological Series.- Journal of Hydrology, 259, 245-271. 